\section{Omkring Christoph Heers Monumentum-håndskrift}

Afafdelingsbibliotekar Bjørn Westerbeek Dabl, Radhusbiblioteket i Kobenhavn

I Håndskriftafdelingen findes der et bind med 22 indklæbede planer af danske, holstenske og norske fæstninger. ${ }^{1}$ De er omhyggeligt udført og smukt koloreret i stærke farver, der synes lige så friske som ved tilblivelsen omkring 1660. Kortene er udstyret med et fælles titelblad, der fortæller, at de er blevet tegnet af "Christophorus Heer", og af ham er tilegnet Frederik den 3. Håndskriftet hører derfor sandsynligvis til blandt bibliotekets $æ l d r e$ dele, selvom det først nævnes i kataloget over bibliotekets manuskripter fra $1784 .^{2}$

De 22 planer er indbundet i et nu temmelig slidt, rødt fløjlsbind, som tidligere har kunnet lukkes med to snoreanordninger, der dog forlængst er knækket af. Bindet omfatter ni ark med i alt 41 blade af gråt kardus. Heraf er kun den første halvdel benyttet. Som angivet på titelbladet, er alle kortene i samme måleforhold (ca. 1:6.877). Det betyder, at kortene varierer i størrelse, afhængigt af den pågældende fæstnings udstrækning: Kortet over København har således måttet falses for at kunne rummes i bindet, otte af kortene omfatter et helt opslag, ${ }^{3}$ mens resten kan holdes på en enkelt side. ${ }^{4}$

$\mathrm{F}$ oruden kortenes oplysninger om de enkelte byers fæstningsværker, viser en del også alment topografiske detaljer som gadenet, monumentalbygninger og landskabsformer. Det er påfaldende, at disse oplysninger ikke er påført konsekvent, og dette forhold kunne antyde planernes enten direkte eller indirekte udspring i en varieret samling af kort. Hver plan er udstyret med et titelfelt i form af en smuk ornamental kartouche i grisaille, hvoraf de fleste er kopieret fra kort, udgivet af nederlandske kartografer i første halvdel af 1600-tallet. Af mere speciel karakter er Københavnskortets kartouche, der er udformet som en stor rektangulær kasse, set i perspektiv. Kassen ligger i vand, omgivet af bølger med hvide skumtoppe. Kortets titel er gengivet på kassens , „lag", den ene langside udgøres af et Dannebrogsflag, mens selve hovedfeltet står gabende tomt. En lignende kasse fungerer som titelfelt på Gottfried Hoffmanns kort over det vestlige Skåne fra efteråret $1657 . .^{5}$

To af titelfelterne består blot af et halvtoprullet skriftbånd, som kendes fra andre sammenhænge, bl.a. Otto Heyders kopier efter Johannes Mejers kort fra 1650'ernes slutning. De er rimeligvis også inspireret fra samtidige nederlandske landkort.

Som noget helt særligt er samtlige titler og kortenes iøvrigt sparsomme tekster trykt ind på papiret med typerne fra et håndstempel (,typetryk“). Det er en teknik, der kendes fra en del danske kort fra årene omkring 1660, der alle entydigt kan føres tilbage til den kreds af ingeniører, der omgav Heer under hans ophold i Danmark.

itelbladet er tvedelt og består af en
triumfbue med en lang smigrende
indskrift på latin, der i oversættelse lyder: „Til den ophøjede og mægtige Herre Frederik den 3., Konge af Danmark, De Venders og De Gothers“... „den uovervin- 


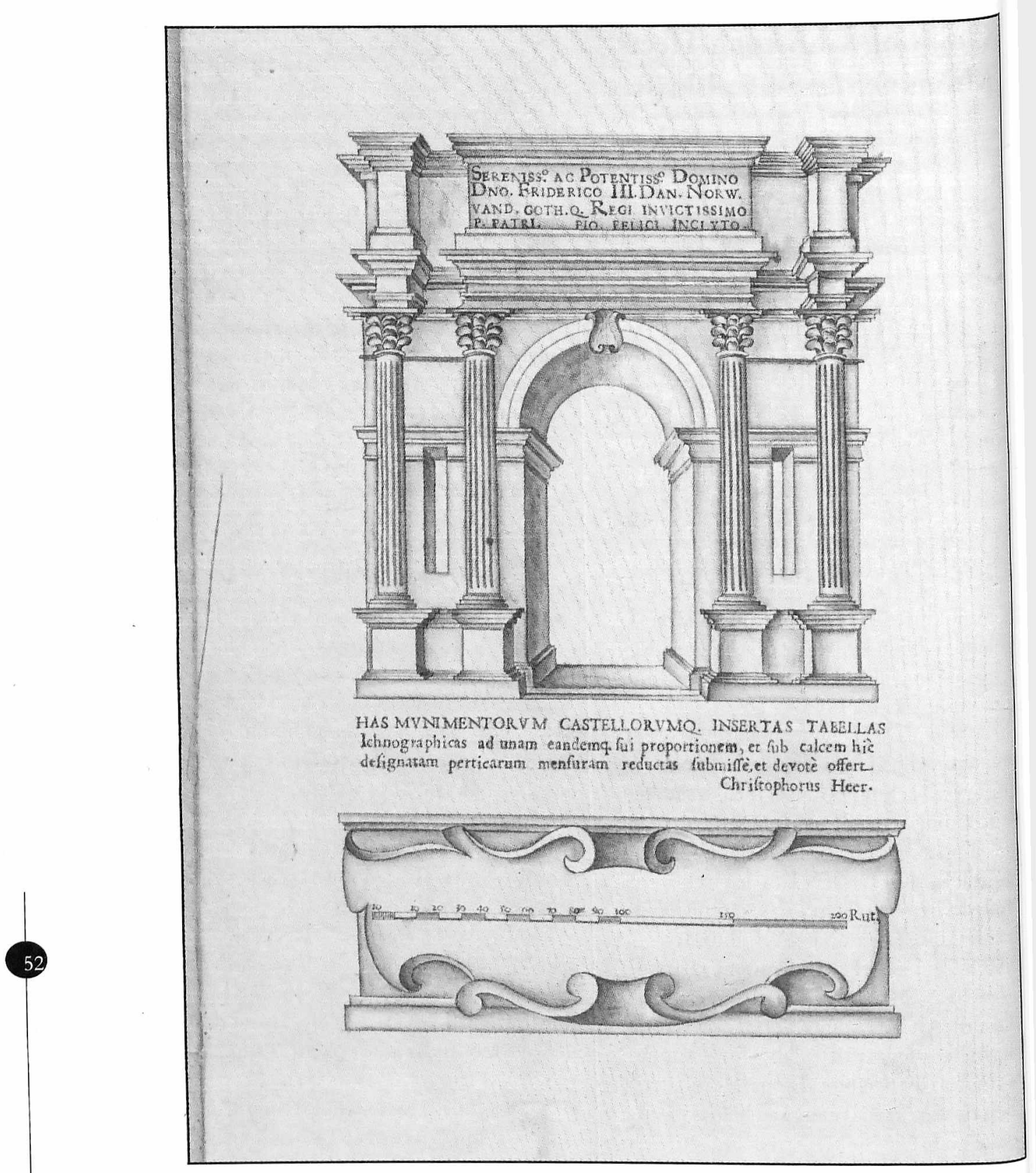

Titelbladet til Christoph Heers Monumentum-håndskrift, med illustration af en triumfbue. (Det Kongelige Bibliotek, Håndskriftafdelingen). 
delige, Fædrelandets Fader, From, Lykkelig, Berømt. "Herunder findes en dedikation fra Heer: „Disse her indføjede kort over frstninger og kasteller, der er fremstillet i ét og samme måleforhold og $i$ henhold til den her gengivne målestok i rodemål, overdrager i al underdanighed Christoph Heer. "

Som titelbladet fortæller, rummer bindet samtlige fæstninger $\mathrm{i}$ kongeriget, $\mathrm{i}$ Norge og i hertugdømmerne, og særligt bemærkelsesværdigt er det, at også fæstningerne i de skånske landskaber er med. Det kunne antyde, at bindet er blevet til før Roskildefreden i februar 1658, men da Heer har gengivet Kronborg, Korsør og Køge med de svenske befæstninger fra sommeren 1659 og første halvår af 1660 , falder en sådan datering bort. Omvendt synes kortene ikke at indeholde oplysninger, der er yngre end sommeren 1661, da Kastellet i København ses i den skikkelse, det havde (eller måske rettere: Skulle have haft), før Ruse i juli 1661 fik godkendt sit projekt. Også Nyborg og Fredericia bærer præg af tilstanden før Ruse planlægning.

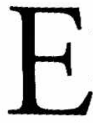

n tilblivelsestid til perioden 1660/61 passer fint ind $i$, hvad vi iøvrigt kender til Christoph Heers ophold i

Danmark, der strakte sig fra 1658 til 1668:6 I de to første år lader han til at have været i lære hos sin fætter ingeniøren Georg Hoffmann. Hans fortjenester indenfor fæstningskunsten fik Heer mange år senere lejlighed til at fremhæve i sin lærebog om frstningskunst, Speculum artis muniendi, som han udgav i Leipzig i 1694.

$$
\text { Georg Hoffmann, der var født i }
$$

Lauban i Schlesien omkring 1610, var kommet $i$ dansk tjeneste som ingeniør under Torstensonskrigen og nævnes første gang $\mathrm{i}$ 1646. To år senere arbejdede han som ingeniør i København og projekterede året efter Frederiksodde (Fredericia). I 1650'erne fortsatte han med afbrydelser sine aktiviteter i København, hvor han synes at have haft ansvaret for opførelsen af en forløber for Henrik Ruses Kastel (,Frederiks Kastel"). I 1655 udarbejdede han en betænkning om Danmarks fæstninger og planlagde en ny by, et Ny-Nyborg, på Knudshoved. Georg Hoffmann deltog i felttoget $\mathrm{i}$ Skåne i efteråret 1657, men blev kaldt til København efter fredsslutningen i 1658, hvor han opholdt sig under belejringen - en tid som kommandant. Efter 1660 synes han muligvis på grund af sygdom - kun undtagelsesvist at have beskæftiget sig med frestningsbyggeri, men var dog medlem af den tremands kommission, der i juli 1661 skulle godkende Henrik Ruses projekt til Kastellet i København, som han iøvrigt ikke fandt tilfredsstillende. Han døde i $1666{ }^{7}$ I marts 1648 var hans yngre broder Gottfried Hoffmann kommet til landet. I de første år var han hos broderen, men ledede fra 1651 opførelsen af fæstningsværkerne omkring Frederiksodde (Fredericia). 1653 blev Gottfried Hoffmann udnævnt til ingeniør i Skåne og forflyttet til Helsingborg, hvor han i de følgende år arbejdede med opførelsen af en ny befæstning omkring byen, der var næsten færdig ved krigsudbruddet i 1657.

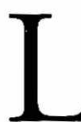

igesom broderen deltog Gottfried Hoffmann i 1. Karl Gustav Krig i Skåne og blev også sendt til København efter fredsslutningen i februar 1658. Han arbejdede i den korte fredsperiode mellem krigene som ingeniør ved hovedstadens befæstning.

Efter 1660 fortsatte han arbejdet

i København og rejste i begyndelsen af 1661 med blandt andre Krigskollegiets præsident Hans Schack på en inspektion 


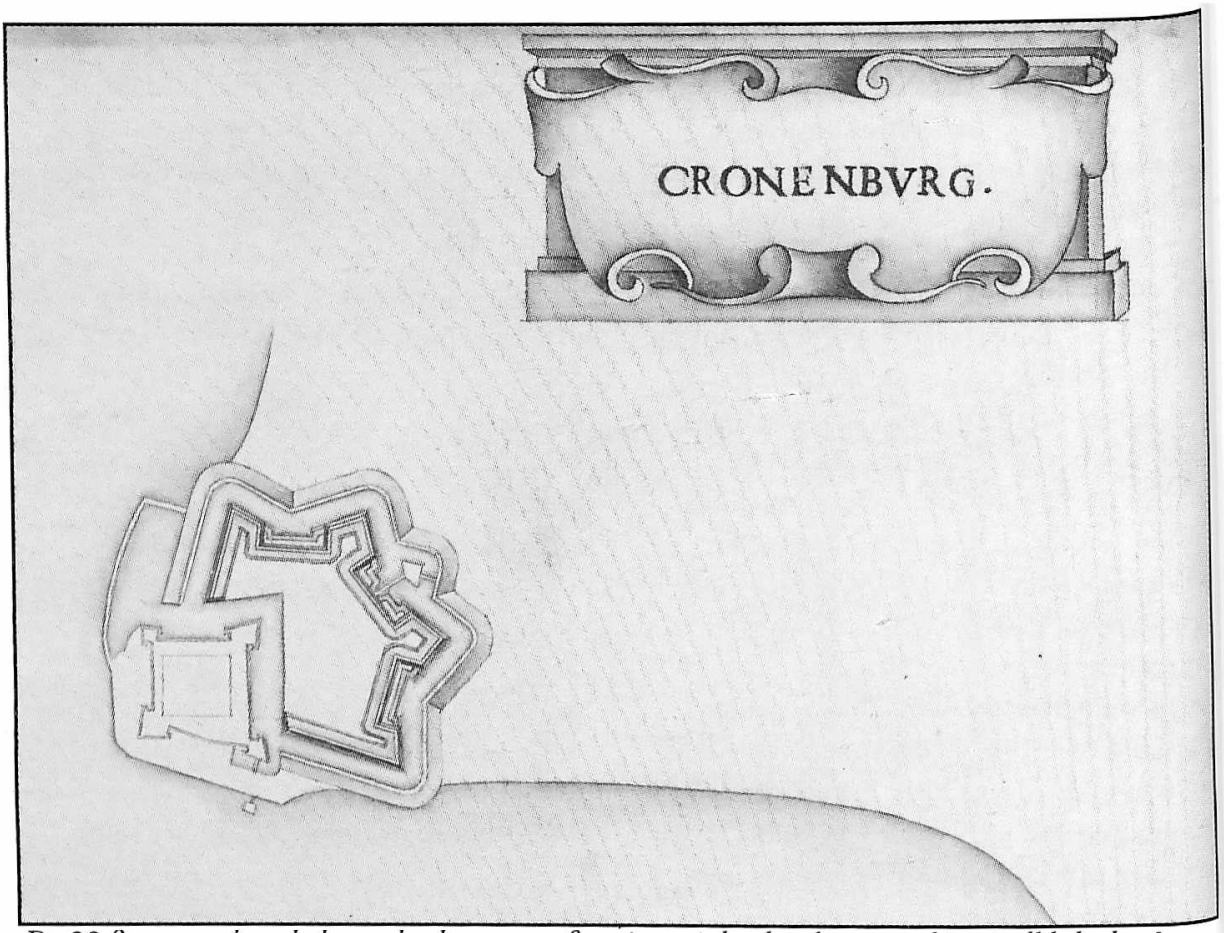

De 22 fint tegnede og kolorerede planer over fastninger $i$ det danske monarki er indklabede $p a$ blade aftykt gråt karduspapir. (Det Kongelige Bibliotek, Håndskriftafdelingen).

rundt $\mathrm{i}$ landet for at rådgive denne $\mathrm{i}$ fæstningsspørgsmål. I 1662 blev han forflyttet til Frederiksodde, hvor han i de følgende ti år genopførte og udvidede befæstningen, der under krigene var blevet totalt ødelagt. ${ }^{8}$

Georg Hoffmann er udførligt omtalt i Niels Steensens Chaosmanuskript fra 1659 , der beretter om, hvorledes den unge Steensen blev indført i naturvidenskabelige og tekniske spørgsmål. Blandt de mange mærkværdigheder, Steensens noterede sig, nævner han den 8. maj, at han har set „en måde at beskrive landkort på med trykte typer", altså netop den teknik, der er benyttet i Heers „Monumentum." Også Christoph Heer nævnes: Om ham

fortæller Steensen, at han var „en svagelig yngling, (der) næsten faldt i en sygdom efter indtagelsen af et afføringsmiddel og udskilte med afføringen nogle store smådele, der var ligesom indviklet i en snor af skind; der var mange af dem. En anden gang, da han var rask, men ikke kunne kaste op, kastede han op, som han gerne ville efter at have røget tre piber tobak, men kort efter følgte han en stikkende smerte og ilede til stols, hvor han med undren opdagede, at der var kommet en ret lang orm ud, alene og uden afføring. $" 10$

Thristoph Heer, der som sine to fætre var født i Lauban, kom sandsynlig vis til København mellem de to 


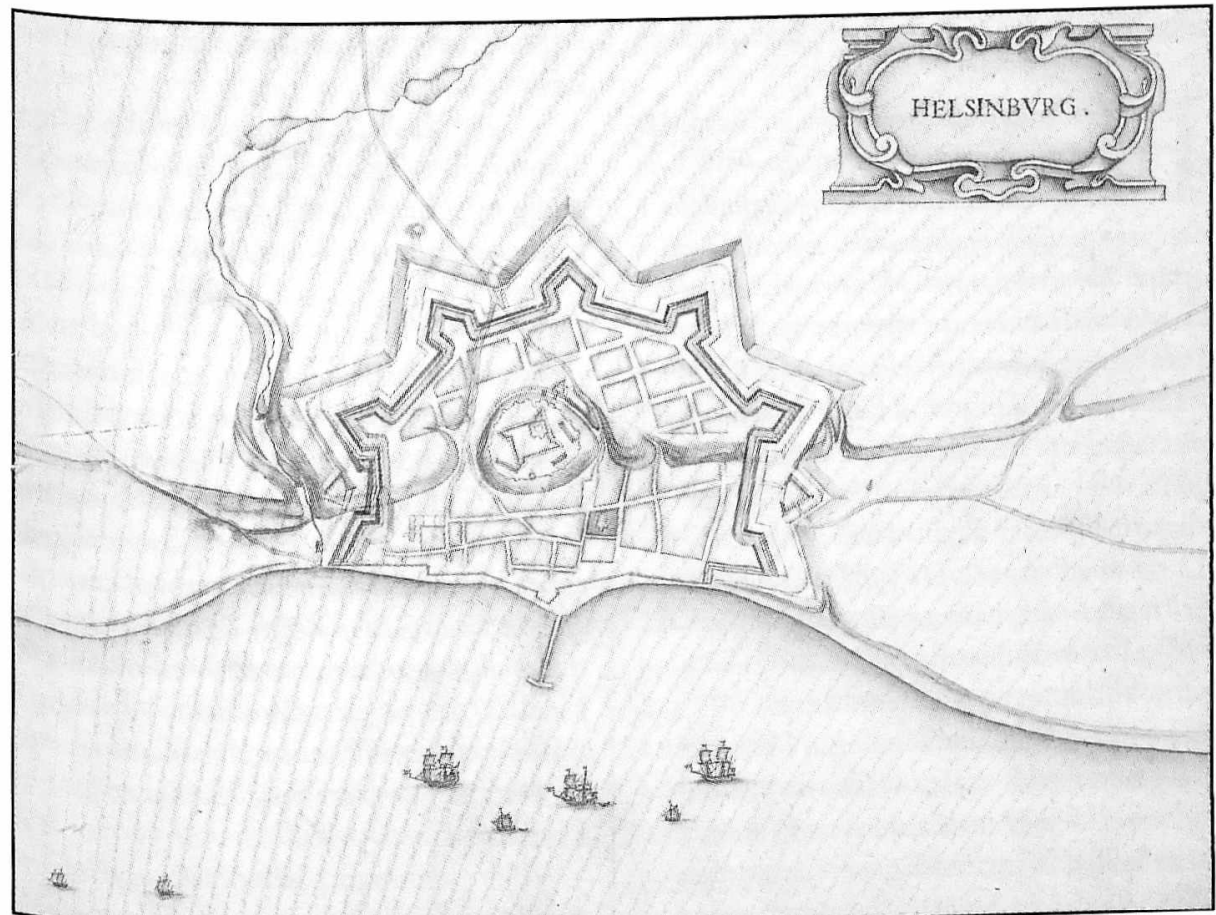

Navnene pà kortene over festningerne er: Aggershus, Bahus, Christianstad, Christianopel, Fredericia, Glückstadt, Halmstad, Hammershus, Helsingborg, Landskrona, København, Kronborg, Koge, Korsør, Laholm, Malmø, Nyborg, Nakskov, Pinneberg, Rendsborg, Sønderborgog Varberg.

Karl Gustav Krige og var her som omtalt i to år under Georg Hoffmanns instruktion. Da Gottfried Hoffmann i 1662 blev udnævnt til ingeniør i Fredericia, foreslog han Hans Schack, at Heer fik lov til at følge med for at lære praktisk fortifikation under hans ledelse. Hoffmann håbede, at han senere kunne få ham ansat som konduktør og medhjælper. Heer kom med til Fredericia, men han blev til Hoffmanns store fortrydelse ikke viderebefordret og måtte leve frem til 1668 på sin fætters nåde og barmhjertighed. Hoffmann forsøgte i 1665 at få ham udnævnt ved at true med, at han ellers måtte sende ham hjem, men forgæves. Det nærmeste Heer kom en regulær ansættelse under sit lange ophold i Danmark var arbejdet ved den ny Strandport i Fredericia i $1665 .{ }^{11}$

Velsagtens som et led i hans uddannelse besøgte han København flere gange og fik herunder forevist Kastellet, der imponerede ham meget. ${ }^{12}$

Fra 1670 var han ingeniør i Strassburg, men i 1681 måtte han flygte til Tyskland ved franskmændenes erobring af byen. Det synes at være sket i en vis hast, for han efterlod sin kortsamling, der ikke blot bestod af et stort antal typetrylkte kort over den nu forhenværende tyske rigsstad, men også et kort over København og en plan af Kastellet. Københavnskortet er i det store og hele identisk med „Monumentum “-kortet over byen og kan supplere dette, hvad angår 
tekstoplysninger og index.

$\mathrm{H}$ eers karrierespring fra underordnet - og ulønnet - medhjælper i Fredericia til ledende ingeniør $\mathrm{i}$ den vigtige tyske rigsstad kan umiddelbart undre: Men udsigterne i Danmark for en ung fremadstræbende ingeniør var $\mathrm{i}$ 1660'ernes slutning håbløs, da man havde standset udbygningen af fæstningerne - på nær arbejder i hovedstaden. Forhandlingerne om hans ansættelse i Strassburg var allerede blevet indledt i 1667, da et af byens 13 rådsmedlemmer, Dr. jur. Johan Adam Schrag, foreslog ham som ingeniør. Det fremgår af rådherrernes forhandlingsprotokol, at man på dette tidspunkt manglede en god ingeniør, og at Heer selv havde henvendt sig for at tilbyde byen sin tjeneste. Heer blev desuden stærkt anbefalet af en kollega til dr. Schrag, professor Julius Reichelt, der underviste i kartografi og matematik ved byens universitet, og som syntes at have kendt Heer (eller Hoffmannbrødrene) personligt. Rådet fandt det dog ikke rimeligt i denne omgang at ansætte en ingeniør, der skulle have 10-12 rdlr. pr. måned, og forslaget faldt derfor til jorden. ${ }^{13}$

Dermed blev Strassburgernes problemer jo ikke løst, og året efter blev der gjort et forsøg på at få Gottfried Hoffmann ansat, men han trak sig hurtigt ud af forhandlingerne på grund af lønspørgsmålet. ${ }^{14}$ Det følgende år blev spørgsmålet taget op igen, da Dr. Schrag endnu engang foreslog at engagere Heer. Truslen fra Frankrig må da have været tydelig for alle, og rådet tiltrådte enstemmigt hans ansættelse som ingeniør til 12 rdlr. pr. måned. Da Heer dukkede op, forsøgte han at fă 18 rdlr. pr. måned, men rådet henviste til, at man kun kendte ham via Julius Reichelts anbefaling af hans „kunst og videnskaber", hvorfor man ikke ville give ham mere end de engang fastsatte 12 rdlr. ${ }^{15}$

$$
\text { Efter sin flugt fra Strassburg }
$$
opholdt Heer sig en del år i Mannheim og endte som lærer ved ingeniørskolen $\mathrm{i}$ Dresden, hvor han døde i 1701.

S om titelbladet til Heers "Monumentum" angiver, er kortene ikke originale opmålinger, men resultatet af et omhyggeligt kopieringsarbejde. Tilfældigvis findes der på Nationalmuseet et sæt fæstningsplaner, der tydeligvis er beslægtet med Heers kort og som kun i ganske ringe grad adskiller sig disse. Selv måleforhold er det samme. ${ }^{16}$ I forhold til Heers 22 planer mangler dog fire kort, og p.t. er kortet over Akershus bortkommet. Omvendt er der ikke flere kort her end i Heers bind.

Kortene på Nationalmuseet er som Heers kort udateret, og uheldigvis også usignerede. Alligevel kan man ved en sammenligning med sikre kortarbejder af Gottfried Hoffmann tilskrive denne kortserien. Den blev i 1864 overdraget museet fra Den Kongelige Kobberstiksamling, der i 1835 var blevet udskilt af Det Kongelige Bibliotek. De kan herfra føres tilbage til arkitekten Lambert van Havens samlinger, som biblioteket erhvervede ved køb i $1690^{\prime}$ erne. ${ }^{17}$ Heri fandtes en del kortplaner, der med sikkerhed kan tilskrives Hoffmann. Det er heller ikke så mærkeligt, idet Lambert van Haven og Gottfried Hoffmann kendte hinanden: Gottfried Hoffmann udstak således $i$ arkitektens nærvær grundarealet til Vor Frelsers Kirke i København i 1682 - og det må anses for sandsynligt, at van Haven har fået kortene direkte af Hoffmann. ${ }^{18}$

Kortseriens planer af Helsingborg, Landskrona og Malmø findes i, hvad 
man kunne opfatte som fragmenterne af et 3. sæt: På Helsingborg Museum findes et blad med Helsingborg og Landskrona. I Kortsamlingen på Det Kongelige Bibliotek i København findes tillige et kort over Malmø, som synes at have hørt sammen med de to kort i Helsingborg på den måde, at det har siddet på samme ark. ${ }^{19}$ Det kan ikke afklares med absolut sikkerhed, fordi Malmøkortets kant uheldigvis er blevet klippet til i nyere tid. En 1700-tals kopi af det oprindelige kort - nu på Tøjhusmuseet med alle tre kort repræsenteret på ét og samme blad synes at bekræfte dette. ${ }^{20}$ Flere af kortene over de skånske fæstninger på Nationalmuseet bærer i øvrigt præg af oprindeligt at have været tegnet parvis på samme ark, men er senere blevet klippet fra hinanden. ${ }^{21}$ Dette gælder påfaldende nok kun kortene over de skånske fæstninger, og måske har dette 3. sæt begrænset sig til fæstningerne Østensunds.

„Kortet" på Helsingborg

Museum og Det Kongelige Bibliotek synes som Nationalmuseets at være tegnet af Gottfried Hoffmann. Hans virkeområde var både Skåne og Blekinge, og det vides, at han blev sendt rundt for at foretage opmålinger af netop fæstningerne i området. Kortene over fæstningerne i Halland, der „midlertidigt" var gået tabt i 1645, må han have kopieret fra ældre kort i danske samlinger.

$\mathrm{E}$ $r$ det 3. sæt muligvis fra 1650'erne, så er der ingen tvivl om, at de to andre sæt begge er fra 1660 eller det følgende år. Netop imellem fredsslutningen $\mathrm{i}$ maj 1660 og Henrik Ruses ansættelse i foråret 1661 var Gottfried Hoffmann kongerigets førende ingeniør, der kunne have gode grunde til at beskrive fæstningernes tilstand kartografisk - det være

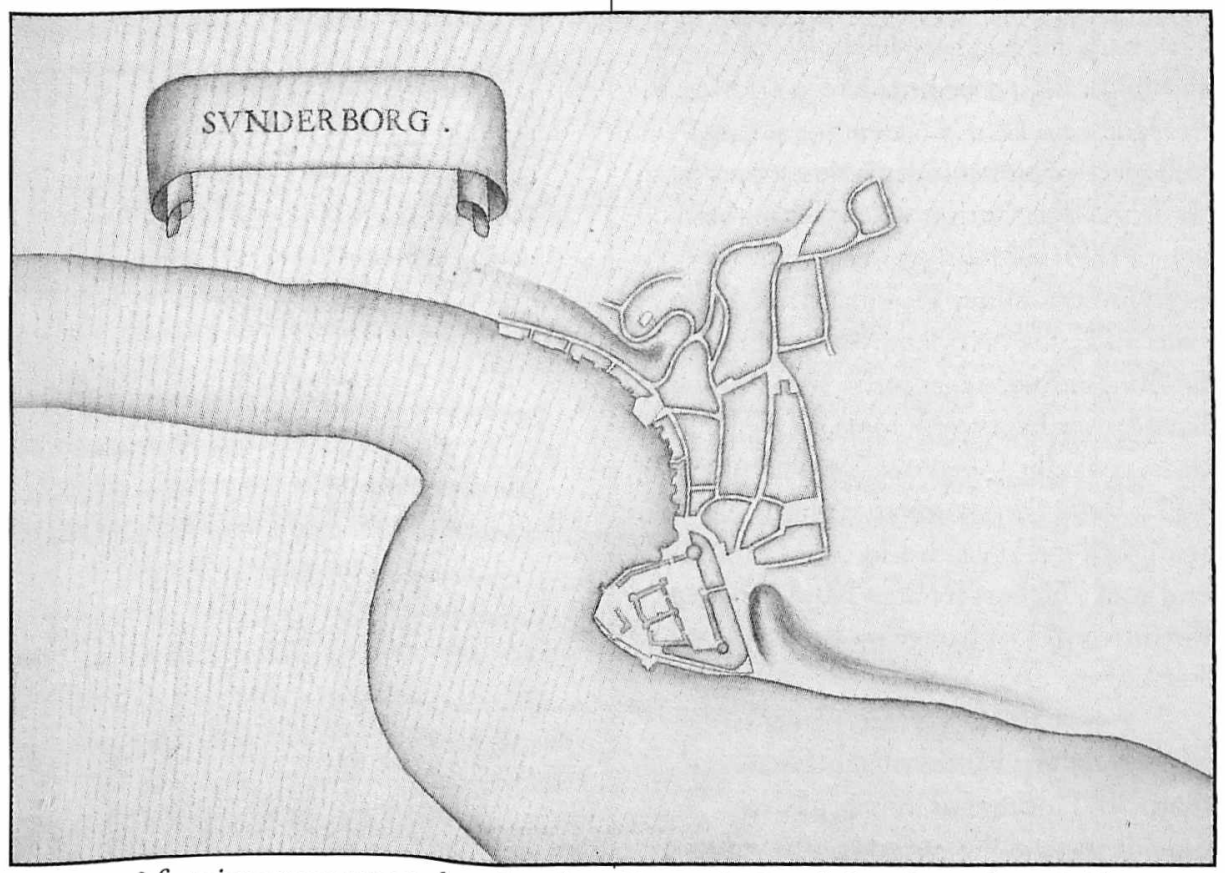

Formen på festningernes navne tyder af og til på Christoph Heers fodested i Lauban i Schlesien.

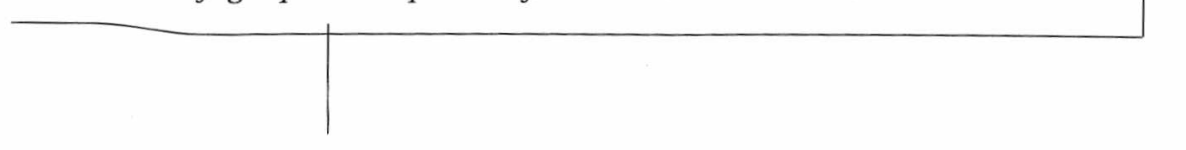


sig til de fæstninger, der var på danske hænder, som de tabte i Skånelandene. Det har været nærliggende for Heer at kopiere fætterens kort, og han havde med ønske om en ansættelse i Danmark al mulig grund til at skænke kongen resultatet af sin flid og dygtighed. Det havde som omtalt ingen effekt. Hans omfattende arbejder som ingeniør i Strassburg, der indtil franskmændenes erobring i 1681 var Tysklands. vigtigste forpost mod vest, antyder dog at hans fætre Georg og Gottfried Hoffmann har været gode læremestre, og at en dygtig ingeniør gik tabt for landet, da han i 1669 forlod København med Strassburg som mål.<smiles>[2H]</smiles>
et er fristende at se Gottfried Hoffmanns kortserie på National museet i sammenhæng med Hans Schacks inspektion af frstningerne i begyndelsen af 1661 . Havde han forestillet sig en fremtid som ledende ingeniør i Danmark, må han være blevet slemt skuffet: I de følgende år arbejdede han ganske vist i Fredericia med direkte reference til Krigskollegiet - uden om Henrik Ruse - men først da denne efter Christian den 5.s tronbestigelse i 1670 var tvunget væk fra sin ingeniørpost, kunne Hoffmann indtage hans plads. Da var tiderne for de store fæstningsudbygninger forbi. Kun i København kunne hans talent folde sig rigtigt ud, bedst ved udbygningen af Christianshavn 1682-1687. Som korttegner gjorde han sig stadigvæk stærkt gældende, og ikke mindre end godt 250 kort fra hans hånd er bevaret fortrinsvis på Det Kongelige Bibliotek og $\mathrm{i}$ Rigsarkivet.

Christoph Heers planer i Monumentum-håndskriftet belyser Gottfried Hoffmanns indsats på dette område fra en tidlig periode $i$ hans virksomhed. Et tilfælde har bevaret størsteparten af hans eget sæt og dele af et 3. sæt, hvorimod forlæggene alle er gået tabt. 
Noter:

1 Gl. Kgl. Samling 716-2

2 Catalogus manuscriptorum Bibliothecx Regiæ in folio. Scriptus et ordinatus Ao 1784. Tom 2.

3 Køge, Fredericia, Kristianstad, Helsingborg, Landskrona, Malmø, Laholm og Glückstadt.

4 Kronborg, Korsør, Nyborg, Nakskov, Hammershus, Halmstad, Varberg, Kristianopel, Båhus, Akershus, Sønderborg, Pinneberg og Rendsborg.

5 Kortsamlingen 1113,111,11-0-1657, x-1965/ 56.

6 G. Hoffmann: Lebens-Geschichte aller evangelischn Pastorum Primariorum, die ... in Lauban gelehret und geleben haben. Lauban 1707, s. 199-215.

7 Bjørn Westerbeek Dahl: Georg Hoffmann og Peter Byssers opmåling af København fra 1648, i: Historiske meddelelser om Kobenhavn 1991, s. 7-31, særligt s. 9-10.

8 Samme: Gottfried Hoffmann. Ingeniør, administrator og militærkartograf ca. 16281687, i: Krigshistorisk tidsskrift 1987. Årg. 23, nr. 1, s. 10-22, jf. sammes: Ophavsmanden til Dania-Norvegiakortet i Det Kongelige Biblioteks Kortsamling, i: Fund og forskning 26 1982/83, særligt s., 38-41.

9 Niels Stensen. En dansk student $i 1659$ og noterne i hans Chaos-manuskript. Ved H. D. Schepelern. 1986, s. 37. - Om Georg Hoffmann: smst., passim. - Kortene: s. 37.

10 Som note 9. Christoph Heer omtales i den trykte udgave som "Christoph Herder", hvilket tydeligvis skyldes en fejllæsning af originalens vanskeligt læselige håndskrift.

11 Zedlers Univesal-Lexikon. Band 12. 1735, sp. 1079. - Rigsarkivet. Privatarkiver 6262 Hans Schack. Brev fra Diderich Busch, 30.5.1665.

12 Heer beskrev Kastellet indgående i Speculum Artis Muniendi, s. 99, $10 \hat{\text { og }}$ 109, jf. Bjørn Westerbeek Dahl: Christoph Heers kort over Kastellet i København, i: Krigshistorisk tidsskrift 1984. Årg. 20, nr. 1, s. 35-39.

13 Archives Municipales de Strasbourg. Protocoll des XIII, 1.7.1667, fol. 299b.

14 Som note $13,4.5 .1668$, fol. 59-a.

15 Som note 13, 20.12.1669, fol. 295b, og 29.12.1669, fol. 296a-b.

16 Nationalmuseet. Antikvarisk-Topografisk Arkiv. Inventarnumerene 538a, n og s.

17 Jørgen Sthyr. Et inventar over Lambert van Havens samling, i: Kunstmuseets Aarsskrift 1939, s. 149.

18 Rigsarkivet. Danske Kancelli. C 8. Sjællandske tegnelser, fol. 441-442, nr. 238, jf. Kjøbenhavns Diplomatarium. Udgivet af $\mathrm{O}$. Nielsen. Bind 7. 1886, nr. 19, s. 9.

19 Helsingborgs Museum, HM 899-41 og: Det Kongelige Biblioteks Kortsamling. Ingeniørkorpsets aflevering, 18-4-1-Malmø c.

20 Tøjhusmuseet. Tegningsarkivet, U-402.

21 Varberg/Båhus og Halmstad/Varberg, der alle nu er klippet fra hinanden. Kortene over Kristianstad og Kristianopel sidder stadig på ét blad, da det lille Kristianopelkort nærmest fungerer so bikort i nederste venstre hjørne af det noget større kort over nabofæstningen. 